drug molecules penetrate resistant trypanosomes. The report suggests that a more rational approach to chemotherapy requires more detailed knowledge of the structure and biochemistry of trypanosomes. And because some enzymes in trypanosomes are more sensitive to certain drugs than are those that catalyse the same reactions in mammalian cells, it adds that it is important that trypanosome enzymes be purified and that detailed comparative studies be made of the kinetics of enzymes from parasite and host cells.

\section{ASTRONOMY DATA}

\section{living with $A p$. J.}

WHAT sources of information are used by astronomers and space scientists in Britain? A three-year survey by the University of Leicester, sponsored by the Office for Scientific and Technical Information, is trying to find out, and the first part of the survey has just been published. Some of its conclusions are mundane; nobody will be surprised, for example, that the universities have a large number of junior research scientists compared with government establishments. But it is remarkable how much British astronomers in particular rely on Astrophysical Journal, published in Chicago and containing articles chiefly by American scientists. Forty-four per cent of astronomers named it as the most generally useful journal, with Monthly Notices of the Royal Astronomical Society a poor second with ten per cent. Space scientists listed Astrophysical Journal with 20 per cent second to Journal of Geophysical Research with 22 per cent, and naturally enough the terrestrial scientists did not mention Astrophysical Journal at all. But when scientists are divided into those doing observational work, those doing theoretical work, and those with a finger in both pies, Astrophysical Journal easily comes out on top in all three categories. The authors of the report, Dr A. J. Meadows and Miss J. G. O'Connor, seem to find the bias to Astrophysical Journal surprising, because it contains few papers from scientists working in Britain - probably, they suggest, because of charges which now amount to $\$ 27.50$ per page. Elsewhere in Europe, astronomers and space scientists seem not to rely on Astrophysical Journal to the same extent, according to Dr. Meadows, who is also worricd about the way Americans depend on Astrophysical Journal even more than do British scicntists, thus missing much of the work going on elsewhere.

This first part of the Leicester survey is based on a questionnaire circulated a year ago, and includes an analysis of the fields studied by British astronomers and space scientists. Most areas of British astronomy, the report says, seem to be fairly well balanced between observation and theory, except for solar research, which is significantly weighted towards observation. The British effort also seems to be fairly evenly distributed through the branches of astronomy, possibly with a slight emphasis on stellar work. As might be expected, a good proportion-21 per cent-are using radio techniques and, significantly, 22 per cent are interested in the "new astronomy" based on observations at X-ray, ultraviolet and infrared wavelengths.

By far the most popular way of keeping up with current research is still by scanning the journalsmore than half those asked preferred this method.
The abstracting services make a poor showing, and are the favourite method of only a fifth of those who replied. Computer retrieval methods are obviously not making much of an impression. Several respondents wanted some method of keeping informed of research in progress. Various suggestions were put forwardjournals should speed up publication, American space research teams should publicize what they are doing before the journal stage, and abstracts of reports written in the course of government-funded research should be more widely circulated.

\section{INFORMATION HANDLING}

\section{Metallurgists in Need}

THE spring meeting of the Institute of Metals was rounded off last week with a discussion on the sources of information. Prompted by the recent report by Aslib on metals information (Nature, 221, 704; 1969), the discussion ranged over the ways in which computers, information officers and journals can help metallurgists to find out what they need to know.

A clear account of the needs of the university metallurgist was provided by Professor R. B. Nicholson of the University of Manchester. He thought that thin specialized journals are best suited to feed a metallurgist with new ideas, but that more comprehensive journals are more useful for carrying out searches. This view was reflected by most of the contributors, who came from both large and small industrial firms as well as from the universities. Mr P. Gregory of BICC stressed the importance of personal contacts and works visits in gaining information. The need for accurate titling of papers was a recurrent theme throughout the meeting.

Several computerized systems for classifying scientific articles were discussed. The most sophisticated of these seems to be the coppcr data centre being set up by the Battelle Memorial Institute in Columbus, Ohio. Mr W. T. Black from Battelle described how data are first collected, evaluated by an expert and then indexed and stored. Mr Black claimed that when the system comes into operation in May, a search for extracts of relevant papers on a given aspect of copper will cost an American with a teleprinter between five and ten dollars.

The problems encountered by smaller firms in getting hold of information were brought out by $\mathrm{Mr}$ Rush of the Industrial Liaison Service, a body set up by the Ministry of Technology to help small and medium sized firms to solve their technological problems. As about 30 per cent of industrial output in Britain comes from firms employing fewer than 200 people, according to an estimate made in 1958 , it is of great importance to keep these firms aware of the latest developments in their fields.

Although the press came in for some frivolous criticism, it was evident that many people still derive a good deal of information from this source. There was widespread chagrin that few metallurgists are literate in more than one language, and one speaker pointed out that about half of all metallurgical papers are not in English. He hoped that the collaboration already in being between the American Society for Metals and the British Institute of Metals would soon spread to a wider front. 